\title{
CLINICAL FEATURES OF THE DIABETIC SYNDROME APPEARING AFTER STEROID THERAPY
}

\author{
*S. E. P. Miller, M.B. (Glasg.) \\ House Physician
}

J. McE. NeILson, M.B., (Glasg.), M.R.C.P

M.R.C.P.Ed., D.P.H.

Senior Registrar

Department of Medicine, Stobhill General Hospital, Glasgow.

IN 1930 Britton showed that extracts of the adrenal cortex administered to normal or adrenalectomised animals caused elevation of the blood sugar and increased the glycogen content of muscle and liver tissue. Subsequently Ingle (1941) reported the occurrence of glycosuria when cortisone was administered to normal rats. Sprague and colleagues, (1950a) described diabetic responses to glucose tolerance tests in patients given 90 to $200 \mathrm{mg}$. of cortisone daily. Since then it has been shown that ostensibly normal human subjects given large doses of corticotrophin or adrenal cortical sterojds may show hyperglycæmia and glycosuria (Conn and Fajans, 1956).

The term "steroid" diabetes was first applied to man by Sprague and colleagues (1950b) to designate the diabetes occurring in a boy with Cushing's syndrome. It has since been suggested (Bastenie, 1956) that the nosological use of the term should be extended to include (1) the diabetes occurring in association with conditions where severe endocrine disorders obviously exist, i.e., in Cushing's syndrome, Achard-Thiers' syndrome and acromegaly; (2) the diabetes in patients with no definite clinical signs of hyperfunction of the adrenal cortex but in whom there is biochemical evidence of hypercorticism,-i.e., certain cases of fat diabetes and the obesity occurring in prediabetes; (3) the aggravation of the diabetic state characterised by increased insulin requirements occurring in the acidosis of insulindependent diabetics following an interruption of insulin supply or as a result of surgical shock or trauma. Selye (1946) postulated that such aggravation might be due to a temporary over-production of the gluco-regulatory corticoids of a defensive nature. To these examples of diabetes produced or aggravated by an increased endogenous supply of adrenal cor-

*Present address-Registrar, Department of Pathology, Glasgow Western Infirmary. ticosteroids must be added; (4) the diabet which occurs as a side effect of the administ tion of steroids. The features of this last type of diabetes are poorly documented.

The present communication describes the clinical features and treatment of five patients who developed diabetes as a result of corticgs trophin or steroid therapy for various unrelated pathological conditions. The terms "steroi\&" and "corticoid" have been used throughout to refer to the so-called glucocorticoids, i.E., the anti-inflammatory and anti-allergic homones secreted by the adrenal cortex or thejr synthetic analogues (McMahon, 1960).

\section{Case Reports}

Case No. 1:

E.B. (Male). Present age 20 years. No foily history of diabetes. Birth weight less than 9.-18. (4.1 kg.). Birth weight of female sibling also with normal limits.

Admitted in April, 1955, with a nephrotic sye drome. Improved after dietary and diuretic thera.8. Readmitted with return of œdema in September, 1955; on the 30th of the same month he was given corticotrophin 20 i.u. intramuscularly six hourß. Twelve days later, after a total of 1,150 i.u. of corticotrophin his urine became green to Benedicts. On the following day the urine was yellow to Benedict's. Thereafter, although hyperglycæmia controlled by 24 to 40 units of soluble insulin per day, his glycosuria remained appreciable until two days after corticotrophin was discontinued on the 19 th of October. Over this period there was no acetonuria. In the succeeding five months without any therapy his urine remained free of glucose.

Because proteinuria and cedema persisted from the 11 th to the 13th March, 1956, he was given prednisolone $10 \mathrm{mg}$. orally six-hourly, to a to of $90 \mathrm{mg}$. without, however, the re-appearance of glycosuria. On the 27th March prednisolone wos again given in the same dosage. The next day 1 R fasting blood sugar was $408 \mathrm{mg} . / 100 \mathrm{ml}$. and both glycosuria and acetonuria were present. Insulin zige suspension lente, 20 units daily, was given from the 28 th March onwards. On the 29th prednisolone was discontinued after $90 \mathrm{mg}$. had been given. By the

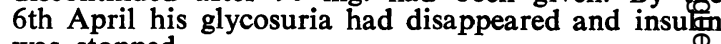
was stopped.

Over the period from 11th April to 16th Mây he received $295 \mathrm{mg}$. of prednisolone orally. This necessitated a rapid increase in daily IZS lente $\Phi_{0}$ 
60 units but it was possible to reduce this to 40 units per day when prednisolone was discontinued again.

A further course of prednisolone was given (total 2.25 g.) between the 7th June and 10th August, 1956. By this time his daily insulin zinc suspension lente requirement on a 2,600 calorie diet $(250 \mathrm{~g}$. of carbohydrate) had risen to 80 units.

Subsequently between 1958 and 1960, although his odema did not return and his albuminuria remained slight, he was re-admitted on numerous occasions with various infections. These included pneumonia twice, upper respiratory and urinary tract infections, acute appendicitis, a subcutaneous abscess and food poisoning.

From October 1960 he has been well and attending as an out-patient. When last seen he was receiving a combination of protamine zinc (68 units) and soluble (28 units) insulin. His diet was 2,800 calories (250 g. of carbohydrate).

\section{Case No. 2:}

C.W., a married female aged 61 had had generalised psoriasis for fifteen years. She was not overweight. The birth weight of one of her two children was 9 pounds 13 ounces $(4.5 \mathrm{~kg}$.). Her own birth weight was not known. There was no family history of diabetes mellitus. During a previous admission to the Dermatological Unit she had at times required treatment for chronic bronchitis and resultant congestive cardiac failure but frequent examinations of her urine for glucose had all been negative.

In June 1961, she was given betamethasone $4 \mathrm{mg}$. daily for the psoriasis and fifteen days later, after a total of $53 \mathrm{mg}$., her urine became orange to Benedict's. An oral $50 \mathrm{~g}$. glucose tolerance test gave the following results:- Fasting blood sugar $186 \mathrm{mg} /$ $100 \mathrm{ml}$., half-hourly levels 274, 354, 357, 274 mg. $/ 100 \mathrm{ml}$.

During the next four weeks betamethasone was progressively reduced and an unsuccessful attempt was made to control her glycosuria by diet (1500 calories; $150 \mathrm{~g}$. of carbohydrate) alone. When chlorpropamide, $500 \mathrm{mg}$., daily was given the glycosuria disappeared completely within twenty-four hours. Betamethasone was finally discontinued in August, 1961 and chlorpropamide was withdrawn in December of the same year.

There has been no return of glycosuria since and her diet is now unrestricted.

\section{Case No. 3:}

S.C., a married male aged 54 had had psoriasis for forty-five years. His wife had had sixteen pregnancies. The birth weight of the first child was 11 pounds $(5.0 \mathrm{~kg}$.) but none of the others was more than nine pounds $(4.1 \mathrm{~kg}$.). Four of the pregnancies resulted in miscarriages. Two other children died within a few hours of birth. The patient's birth weight was unknown. A paternal aunt had diabetes.

Since 1958 he had attended the Dermatological Unit and on two occasions his psoriasis had required in-patient treatment. On those occasions there had been no glycosuria.

On January, 28th, 1962 he was given $32 \mathrm{mg}$. of triamcinolone in divided doses. On the following day his urine gave an orange reduction of a Clinitest tablet. Next day his fasting blood sugar was $160 \mathrm{mg} . / 100 \mathrm{ml}$. A week later an oral $50 \mathrm{~g}$. glucose tolerance test gave the following results:-Fasting blood sugar $157 \mathrm{mg} . / 100 \mathrm{ml}$., half-hourly levels 199, $236,271,259 \mathrm{mg} . / 100 \mathrm{ml}$.

A 1800 -calorie diet (180 g. of carbohydrate) and $0.5 \mathrm{~g}$. of chlorpropamide daily had no effect on his glycosuria, while triamcinolone was gradually being reduced. Metformin $0.5 \mathrm{~g}$. thrice daily was added and this combined therapy resulted in a fall in his fasting blood sugar to $112 \mathrm{mg}$. $/ 100 \mathrm{ml}$. within three days. His urine however continued to give orange results to Clinitest during the day. Occasionally there were traces of acetone in the urine. It was fully five weeks before diet and the two oral hypoglycæmic substances achieved adequate control of the glycosuria. By that time triamcinolone had been reduced to $10 \mathrm{mg}$. daily. In April he was discharged home on this dosage of triamcinolone. In addition, he took metformin $0.25 \mathrm{~g}$. three time a day and $0.5 \mathrm{~g}$. chlorpropamide daily.

In June 1962 while still on triamcinolone he had a hæmatemesis and the drug was subsequently gradually withdrawn. Shortly thereafter it was found possible to stop the metformin. Chlorpropamide was stopped in December, 1962.

In January of last year, he was allowed an unrestricted diet without the reappearance of glycosuria. An oral 50 g. glucose tolerance test in February of this year showed normal carbohydrate tolerance but a cortisone-augmented glucose tolerance test shortly afterwards gave the following results:Fasting blood sugar $97 \mathrm{mg} . / 100 \mathrm{ml}$. half-hourly levels $145,172,186,134,69 \mathrm{mg} . / 100 \mathrm{ml}$.

The psoriasis is relatively quiescent at present.

\section{Case No. 4:}

N.McC., a married woman aged 54 had had rheumatoid arthritis since 1935 . Of eight pregnancies two had resulted in miscarriage. Both her first and fourth children had weighed approximately 14 pounds $(6.4 \mathrm{~kg}$.) at birth. Her own birth weight was not known. Her elder sister, who died at the age of 73 , was a diabetic. In 1958 the patient had a myocardial infarction from which she recovered satisfactorily. While an in-patient at that time, traces of glycosuria were noted twice.

In October, 1959, while attending the Rheumatic Clinic, she was given prednisolone $10 \mathrm{mg}$. daily. This was continued, with minor variations in the dose for more than two years, during which time she was admitted on three occasions for gynæcological investigation of post-menopausal bleeding. Her weight increased steadily from 13 stones 2 pounds $(83.6 \mathrm{~kg}$.) to 14 stones 6 pounds $(91.7 \mathrm{~kg}$.) and her appearance became Cushingoid but there was no glycosuria. In January, 1962, $6 \mathrm{mg}$. of paramethasone daily was substituted for prednisolone. In March she developed symptoms of diabetes (see Table 1) but glycosuria was not discovered until she attended hospital in April-four weeks later. At that time she was 12 stones 12 pounds $(82 \mathrm{~kg}$.) - $35 \%$ overweight. Her fasting blood sugar was $239 \mathrm{mg} . / 100 \mathrm{ml}$. Paramethasone was reduced to $2 \mathrm{mg}$. per day. After four weeks of a 1000-calorie diet she had lost 13 pounds $(8.5 \mathrm{~kg}$.) in weight. Her symptoms had abated and her glycosuria had disappeared.

Since May 1962 her weight has fallen steadily until in February of last year she weighed 11 stones 6 pounds $(73 \mathrm{~kg}$.). Her joint symptoms are controlled by $4 \mathrm{mg}$. of paramethasone daily. There has been no return of glycosuria. An oral $50 \mathrm{~g}$. glucose tolerance 
Oral Glucose Tolerance Test at onset of Diabetes.

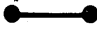

Oral Glucose Tolerance Test

Four Months later. $(12 \cdot 3 \cdot 63)$
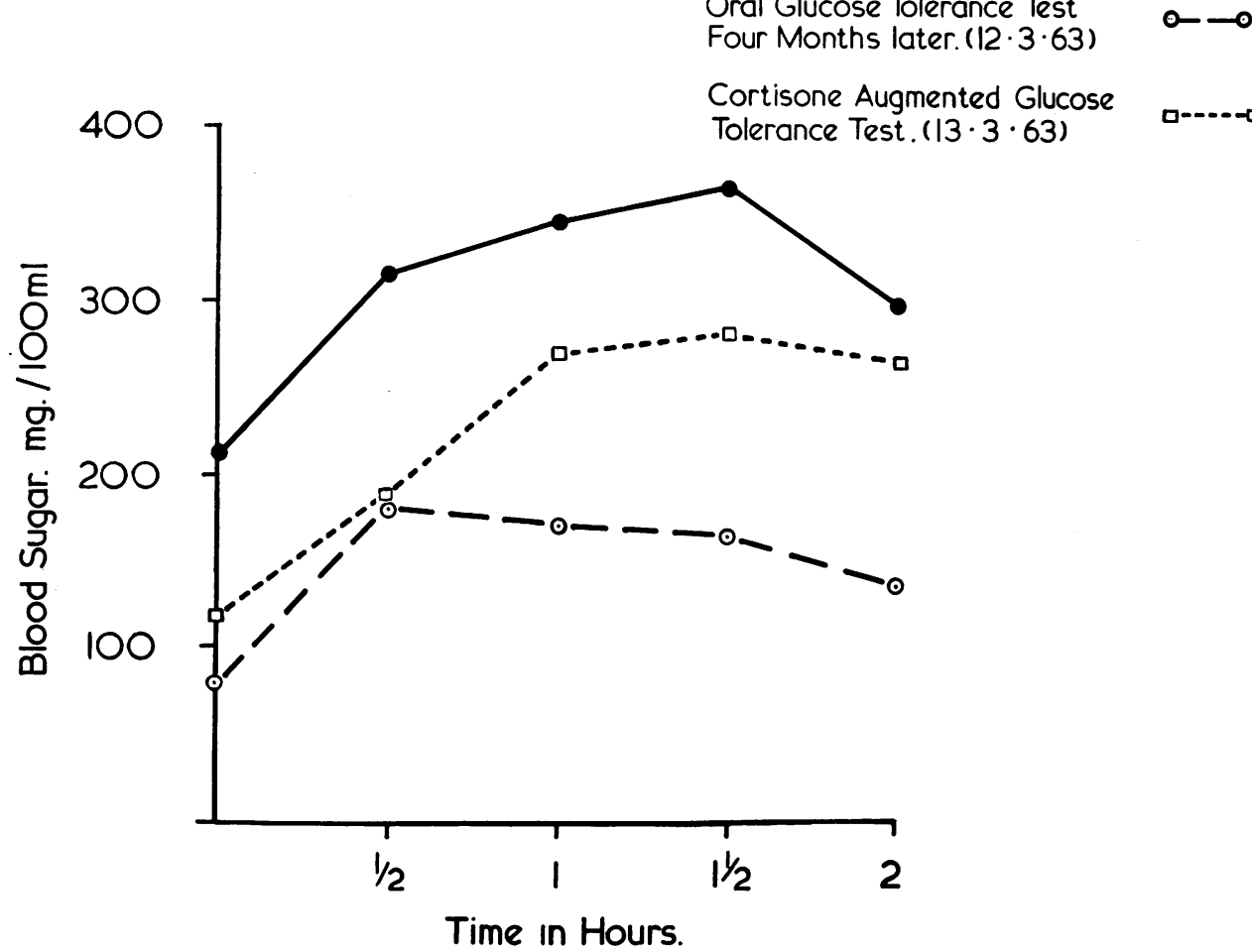

Fig. 1.-Glucose Tolerance Tests for Case 5.

test in February 24, 1962 however still showed a moderate diabetic response:-Fasting blood sugar $154 \mathrm{mg} . / 100 \mathrm{ml}$., half-hourly levels 296, 324, 268, $231 \mathrm{mg} . / 100 \mathrm{ml}$.

A cortisone-augmented glucose tolerance test two days later was essentially similar, although the 2-hour blood sugar level was proportionately higher than the fasting blood sugar in this test:-Fasting blood sugar, $138 \mathrm{mg} . / 100 \mathrm{ml}$., half hourly levels 245 , $257,269,226$, mg./100 ml.

\section{Case No. 5:}

M.McD., a widow aged 62 years had had psoriasis for five years. Her eleven pregnancies had been normal. Her own birth weight was within normal limits and none of the birth weights of her children exceeded 10 pounds $(4.5 \mathrm{~kg}$.). There was no family history of diabetes.

On the 16th October, 1962, she was given triamcinolone, $32 \mathrm{mg}$., daily, to control an acute exacerbation of her psoriasis. Twelve days later, after a total of $392 \mathrm{mg}$. of triamcinolone, glycosuria appeared. On the following day, a fasting blood sugar was $206 \mathrm{mg}$. $/ 100 \mathrm{ml}$. Triamcinolone was progressively reduced thereafter by $4 \mathrm{mg}$. per day. An oral $50 \mathrm{~g}$. glucose tolerance test was performed at the onset of glycosuria and showed a diabetic-type of response. (see Fig. 1). A 1000 calorie diet alone failed to control her glycosuria but when metformin $0.5 \mathrm{~g}$. three times daily was added, her glycosuria subsided, after eleven days. The dosage of metforminह was gradually reduced until after three weeks it was discontinued. By this time she was receiving $8 \mathrm{mg}$ of triamcinolone per day and her glycosuria hado not returned.

In March of last year, while still receiving $8 \mathrm{mg}$ of triamcinolone per day, an oral $50 \mathrm{~g}$. glucoseo tolerance test was repeated and a cortisone-augmented glucose tolerance test (Fajans \& Conn, 1954) was also performed. The results are shown in Figure 1‥

At present she is on a 1000 calorie diet and although still taking $8 \mathrm{mg}$. of triamcinolone daily. she has had no return of glycosuria.

\section{Symptoms at the Onset of the Diabetic Syn- drome}

The first three patients were in hospital when daily urine examination revealed glycosuria All complained of thirst for one day. Thes fourth lost a little weight and had thirst $N$ polyuria and pruritus vulvae for a monthN before the urine was tested for glucose. In ${ }_{0}^{\omega}$ the fifth patient, thirst, polyuria and pruritus vulvae occurred for a week after commencement of paramethasone therapy and recurred together with glycosuria, 13 days after triam:cinolone (32 mg. daily) had been started. 


$$
\text { 䈉 }
$$

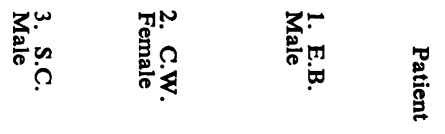<smiles>C1CC1C1CC1</smiles>

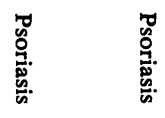

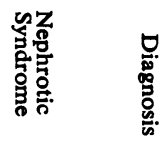

ลิ

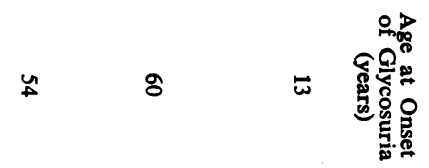

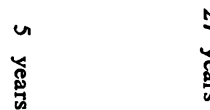

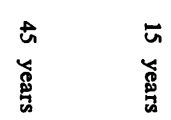<smiles>C=CCCCC</smiles>

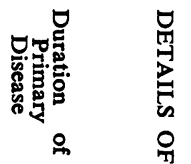

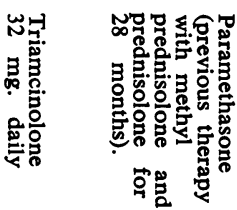

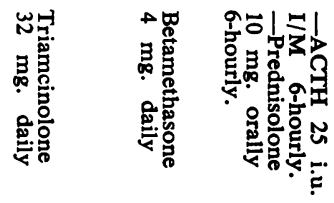

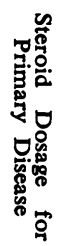

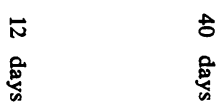

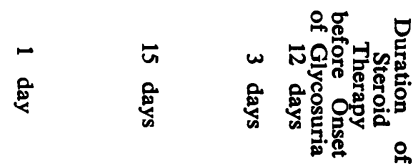<smiles>C[13CH][13CH]</smiles>

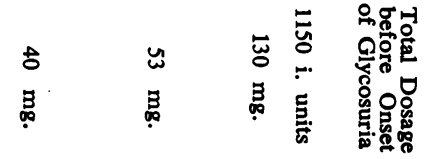


TABLE 2

SALIENT FEATURES OF PREVIOUSLY RECORDED EXAMPLES OF DIABETES MELLITUS FOLLOWING STEROID THERAPK

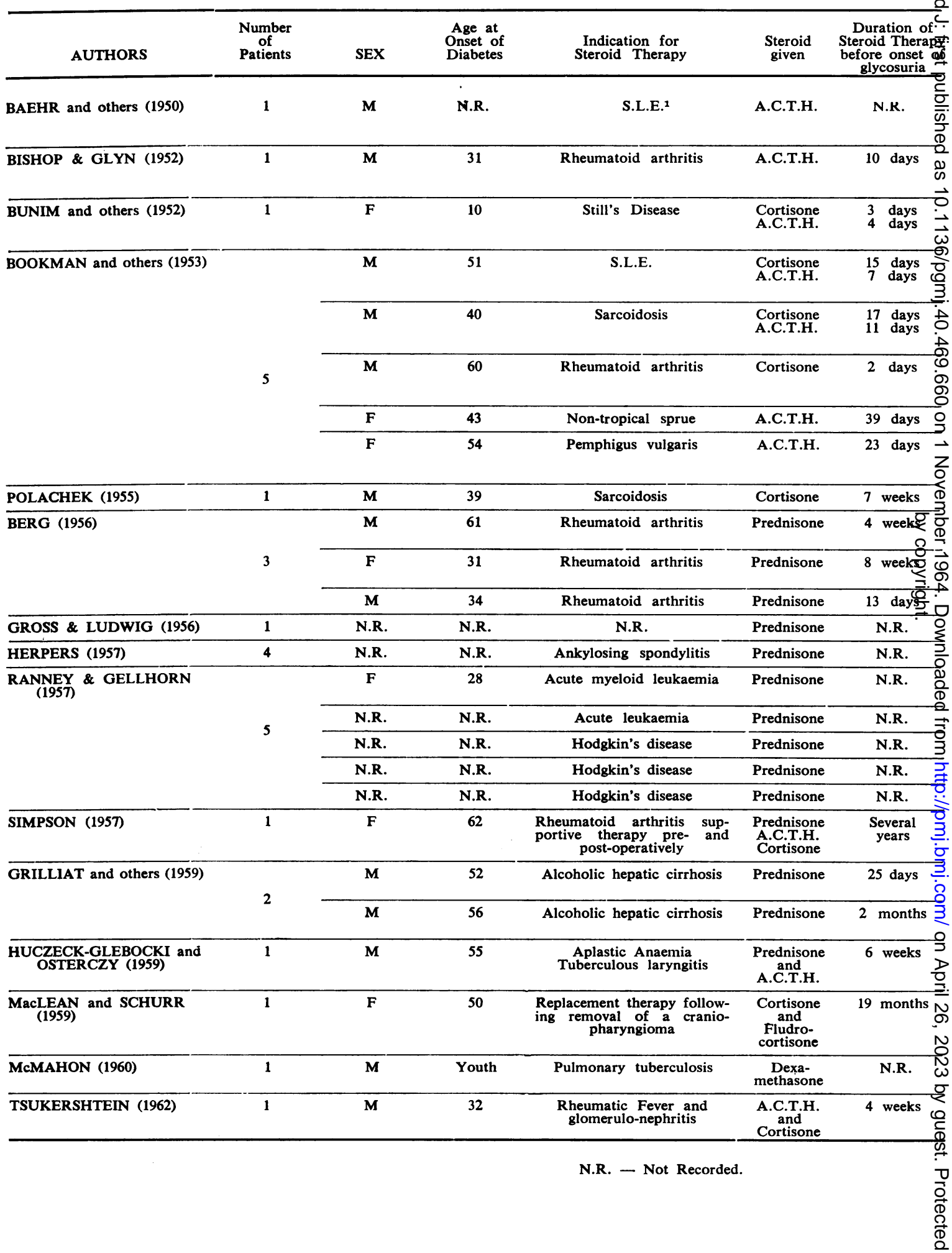


TABLE 2

SALIENT FEATURES OF PREVIOUSLY RECORDED EXAMPLES OF DIABETES MELLITUS FOLLOWING STEROID THERAPY

\begin{tabular}{|c|c|c|c|c|c|}
\hline $\begin{array}{l}\text { Family History } \\
\text { of Diabetes }\end{array}$ & $\begin{array}{l}\text { Other Evidence of } \\
\text { Prediabetes }\end{array}$ & Ketosis & $\begin{array}{l}\text { Insulin } \\
\text { Sensitivity }\end{array}$ & $\begin{array}{l}\text { Duration of } \\
\text { Diabetes }\end{array}$ & Diabetic Therapy \\
\hline $\begin{array}{l}\text { Strong family } \\
\text { history of } \\
\text { Diabetes }\end{array}$ & None & N.R. & $\begin{array}{l}\text { Relatively } \\
\text { insulin } \\
\text { resistant }\end{array}$ & N.R. & 100 units soluble insulin given \\
\hline None & N.R. & $\mathrm{Nil}$ & $\begin{array}{l}\text { Initially } \\
\text { sensitive }\end{array}$ & ? lasting & $\begin{array}{r}200 \text { grams. carbohydrate in diet. } \\
50 \text { units soluble insulin twice } \\
\text { daily }\end{array}$ \\
\hline None & G.T.T. $^{2} \begin{array}{c}\text { None } \\
\text { before cortisone } \\
\text { was normal }\end{array}$ & None & Sensitive & Temporary & Diet, 50 units soluble insulin \\
\hline $\begin{array}{l}\text { Mother, sister } \\
\text { and paternal } \\
\text { cousin }\end{array}$ & None & None & Resistant & 3 months & $\begin{array}{l}350 \\
15-110^{\text {g. }} \text { units soluble insulin per } \\
\text { day }\end{array}$ \\
\hline $\begin{array}{l}\text { Two paternal } \\
\text { uncles }\end{array}$ & None & None & $\begin{array}{l}\text { Insulin } \\
\text { Tolerance } \\
\text { normal }\end{array}$ & 5 weeks & N.R. \\
\hline None & $\begin{array}{l}\text { Glycosuria noted on one } \\
\text { occasion } 10 \text { years before } \\
\text { steroid therapy }\end{array}$ & None & N.R. & $\begin{array}{l}\text { G.T.T. still } \\
\text { abnormal } 15 \\
\text { months later }\end{array}$ & Protamine zinc insulin 25 units \\
\hline Father & None & None & N.R. & Temporary & None \\
\hline Mother & None & $\begin{array}{l}\text { Acetonuria } \\
\text { ? starvation } \\
\text { ketosis }\end{array}$ & $\begin{array}{l}\text { Relative } \\
\text { resistance }\end{array}$ & $\begin{array}{l}\text { Glycosuria } \\
\text { persistent }\end{array}$ & N.P.H. insulin-up to 70 units \\
\hline None & None & None & N.R. & Temporary & N.R. \\
\hline None & $\begin{array}{c}\text { Glycosuria noted } 21 \text { years } \\
\text { previously }\end{array}$ & Acetonuria & N.R. & N.R. & N.R. \\
\hline $\begin{array}{l}\text { Maternal } \\
\text { grandmother }\end{array}$ & None & None & N.R. & Temporary & Diet alone \\
\hline None & None & None & N.R. & Temporary & Diet and carbutamide \\
\hline N.R. & N.R. & N.R. & N.R. & ? Temporary & N.R. \\
\hline N.R. & N.R. & N.R. & N.R. & Temporary & N.R. \\
\hline N.R. & N.R. & N.R. & N.R. & Temporary & N.R. \\
\hline N.R. & N.R. & N.R. & N.R. & Temporary & N.R. \\
\hline N.R. & N.R. & N.R. & N.R. & N.R. & N.R. \\
\hline N.R. & N.R. & Present & N.R. & N.R. & N.R. \\
\hline N.R. & N.R. & Present & N.R. & N.R. & N.R. \\
\hline None & $\begin{array}{l}\text { Previous G.T.T. showed } \\
\text { mild diabetic response }\end{array}$ & Acetonuria & $\begin{array}{l}\text { Relative } \\
\text { insensitivity }\end{array}$ & N.R. & $\begin{array}{l}\text { Soluble insulin. Intravenous fluid } \\
\text { and electrolyte therapy }\end{array}$ \\
\hline N.R. & Previously elevated blood & Acetonuria & Sensitive & $\begin{array}{l}\text { Died after } \\
4 \text { months }\end{array}$ & 80 units of soluble insulin daily \\
\hline N.R. & None & None & N.R. & 1 month & 20 units of soluble insulin daily \\
\hline N.R. & N.R. & None & N.R. & $\begin{array}{l}\text { Died after } \\
5 \text { months }\end{array}$ & $\begin{array}{l}\text { Carbohydrate restriction and } 20 \\
\text { units soluble insulin daily }\end{array}$ \\
\hline N.R. & N.R. & None & N.R. & $\begin{array}{l}\text { More than } \\
4 \text { months }\end{array}$ & N.R. \\
\hline N.R. & N.R. & N.R. & N.R. & N.R. & N.R. \\
\hline None & None & None & Sensitive & 20 days & $\begin{array}{l}160-220 \mathrm{~g} . \\
\text { to } 20 \text { units soluble insulin daily }\end{array}$ \\
\hline
\end{tabular}

1. S.L.E. - Systemic Lupus Erythematosus.

2. G.T.T. - Glucose Tolerance Test. 
The symptoms are evidently no different from those in the 'idiopathic' form of the disease and should be looked for in patients on steroid therapy, as they may coincide with the onset of glycosuria.

In Case 1, diuresis occurred as the result of the treatment of the nephrotic syndrome by ACTH, rather than to the onset of the glycosuria. There was no fall in the plasma bicarbonate and no ketonuria, both of which were marked five months later when prednisolone was given.

\section{Evidence of Prediabetes}

Renold (1959) stated that, "In the few instances where discontinuation of hormone administration was not followed by disappearance of the diabetic syndrome present during excessive adrenal cortical hormone activity, pre-existing diabetes could not conclusively be ruled out and indeed was suggested by a careful past history or by the presence of a suggestive family history."

In this series however, in Case 1 diabetes persisted although there was no evidence of pre-existing diabetes. He had been under inpatient observation before the onset of glycosuria and his urine had been examined frequently for glucose with negative results. Careful enquiry failed to reveal a family history of the disease. The findings in Case 5 were also negative. Cases 3 and 4 had close relatives with the disease.

Berg (1956) and Huczek-Glebocki and Osterczy (1959) have already emphasised the importance of careful enquiry into the family obstetric and past histories of patients to whom steroids are to be given. Even if a positive family or suspicious obstetric history does not absolutely forbid the use of steroids, such features should serve as warnings of the possible development of diabetes. Closer observation of such patients is indicated and daily examination of the urine for glucose is essential.

A satisfactory definition of the term 'prediabetes' has yet to be made. If one accepts those features which Jackson (1959) suggests are manifestations of the 'pre-diabetic' state, the remaining three patients all had evidence of 'pre-diabetes'.

Cases 2 and 3 had borne children weighing over 9 lbs., while in case 4 two had weighed between 13 and 14 lbs. Case 3 had had four miscarriages and case 4 , two, while the former lost two infants immediately after birth. Case 4 gained weight rapidly after her 8th preg- nancy, developed angina at the menopause and had glycosuria after a myocardial infarc 3 tion. There were no other manifestations of prediabetes in this series.

\section{Details of Steroid Therapy}

See Table 1

In each of the five patients illustrated ther $\frac{\overline{ }}{\bar{x}}$ was clear indication for the use of steroids $\overline{\mathrm{D}}$ In all the patients steroids were used when other measures had failed, and in the face of a deterioration in the patient's condition.

The total dose of steroid administered before the onset of a symptom or sign suggesting diabetic state, varied from as little as $40 \mathrm{mgo}$ of triamcinolone, (Case 3) to as much as $392 \mathrm{mg}$. of triamcinolone (Case 5), and in the instance of Case 4 a very considerable amounf of steroid must have been administered ove? the years.

The time elapsing between the initial doses of steroid and the appearance of diabetig symptoms varied from one day, which is virtually instantaneous, to more than 40 days $z$ in Case 4.

\section{Duration and Treatment of the Diabetes}

Table 1 shows that the duration of glyes suria in four of the five patients varied froms five weeks to six months. In Case 1 the da betic state has remained established for more than eight years, although steroid therapy hass not again been given in that time.

The severity of the diabetes has also varied Case 4 required only a 1,000 calorie diee to control the glycosuria. Three of the other $\vec{B}$ required treatment with oral hypoglycæmic agents and in one of those, both chlorpro? pamide and metformin were necessary before. the glycosuria was controlled. Case 1 againg differed markedly from the others in that the diabetes was severe and there was no alternative to administration of insulin. He was the only patient whose acetonuria was gross. If is striking that this patient, whose diabetes was the most severe and which has proved to be lasting was one of the two cases in which theres was no evidence of prediabetes. It is possible that some of this lack of evidence can bes related to the patient's sex and his youth 0 since many of the features of prediabetes liev in a patient's obstetric history.

The possibility of diabetes occurring as $\underset{a}{0}$ side effect of steroid therapy should be con $\frac{0}{\infty}$ sidered and critically evaluated against thes? benefit to be gained before the steroid is intro: duced. Once glycosuria has appeared however, 
there is no indication that therapy for control of the diabetic state should be other than along orthodox lines. If possible the dosage of steroid should be gradually reduced to a level compatible with the attainment or maintenance of therapeutic benefit. If the patient is a young person insulin therapy will probably be required and, if acetonuria is present insulin should be given at once. If the patient is obese and the age of onset of the diabetes exceeds 40 years, an attempt should be made to control the glycosuria by dietary restriction alone. If this fails, chlorpropamide or metformin should be employed alone, or in combination. There may be occasions when the diabetes is of less importance than the control of the pathological condition which necessitated steroid therapy in the first instance and in these circumstances the dosage of steroid should be chosen regardless of the diabetes, and the therapy for the latter altered accordingly.

\section{Discussion}

Ingle (1956) compared diabetes induced experimentally by steroids with pancreatic diabetes in the rat. Among the features of adrenal steroid diabetes he described are the following:-

(1) A tendency toward insulin resistance which becomes remarkably severe in some individual animals; (2) a severe negative nitrogen balance; (3) absence of glycosuria during fasting; (4) reversibility of the diabetes when the administration of hormone is stopped.

Conn and Fajans (1956) described the features of steroid diabetes due to adrenal cortical hyperfunction (endogenous hydrocortisonism, Cushing's syndrome) in man as follows:-(1) great elevation of the fasting blood sugar is very unusual; (2) relative insensitivity to exogenous insulin; (3) ketosis is rare; (4) in the early stage of the disease a negative nitrogen balance exists even when glycosuria is minimal or absent; (5) urinary excretion of 17-hydroxycorticoids is elevated; (6) in contrast to pancreatic diabetes, the levels of blood lactate and pyruvate may be greatly elevated before administration of glucose and they rise promptly to higher levels after the administration of glucose; (7) the diabetic state is reversible and disappears after the surgical removal of the adrenal lesion. The features therefore of the diabetes of Cushing's syndrome in man are similar to those of the steroid-induced diabetes of experimental animals. The diabetes which occurs as a side-effect of steroid administration in man might also be expected to share these same features but an analysis of the five patients reported here and previous reports in the world literature has shown that there may be important differences in the individual patient. With regard to the response of such patients to exogenous insulin, of the 29 previously reported instances of this syndrome (see Table 2) four were insulin resistant. (Baehr, Soffer, Boas, Levitt and Gabrilove, 1950; Bookman, Drachman, Schaffer and Adlersberg, 1953; Simpson, 1957), four were insulin sensitive (Bishop and Glyn, 1952; Bunim, Kaltman and McEwen, 1952; Grilliat, Koenig and Vaillant, 1959; and Tsukershtein, 1962) and one showed a normal response to an insulin tolerance test (Bookman and others, 1953). No information on this point is available in the others. In our series, Case 1 was insulin sensitive at the onset of hyperglycæmia although later he required as much as 100 units of insulin daily. Similarly, although the diabetes which followed corticotrophin therapy for rheumatoid arthritis in the patient described by Bishop and Glyn (1952) was initially insulin sensitive, stabilisation ultimately required 100 units of soluble insulin daily. It is probable that the insulin resistance in their patient was due to continued therapy with cortisone in the dosage of $75-100 \mathrm{mg}$. daily. There is no such easy explanation for the high insulin requirement of our patient since the insulin dosage noted above is still necessary eight years after he was last given prednisolone. None of the other four patients in our series required insulin and insulin tolerance tests were not performed.

In most recorded instances the diabetic state has been temporary and glycosuria subsided when the steroid was discontinued. Permanent diabetes is very rare. Only the male of 31 years of age described by Bishop and Glyn (1952) and two of the patients described by Bookman and others, (1953) have continued to require insulin. To these three patients must be added the first patient in this series whose diabetes is now of eight years duration.

Ketosis is not as rare as has been suggested. Two of our five patients showed marked acetonuria at the onset of diabetes and acetonuria of variable degree occurred in six of the 29 patients summarized in Table 2. In several of the latter however acetonuria may have been the result of inadequate food intake caused by the primary pathological condition for which steroids were given. Polachek (1955) claimed that acetonuria had never been reported with 
steroid therapy even when frank diabetes supervened. This statement can no longer be considered correct.

Great elevation of the fasting blood sugar occurred in only one of our five patients. (Case 1). Here the maximum fasting blood sugar recorded was $590 \mathrm{mg} . / 100 \mathrm{ml}$. The maximum recorded fasting blood sugar in the remaining four did not exceed $240 \mathrm{mg} . / 100 \mathrm{ml}$.

In the production of a diabetic syndrome by steroids neither the nature nor the dosage of the steroid employed would appear to be of major importance. It should be noted, however, that in parallel with the increase in the antiinflammatory effect of the more recent synthetic steroid derivatives, there has been an increase in their effect on carbohydrate metabolism. Of the steroids isolated from the suprarenal cortex hydrocortisone has the most marked effect upon carbohydrate metabolism. Cortisone is next. The synthetic steroids prednisone and prednisolone are approximately four times more potent than hydrocortisone in this respect (Conn and Fajans, 1956). Triamcinolone is 10 to 40 times more active than hydrocortisone in reducing glycogen deposition in rats. (Golding, 1960). It has been suggested (Villa, Ballabio and Sala, 1959) that dexamethasone is less diabetogenic than other steroids but Newman, Dobson and Diraimondo, (1959) failed to confirm this. Examples of diabetes have now been reported following dexamethasone (McMahon, 1960) and the more recently introduced betamethasone (Case 2).

The pathogenesis of the diabetes following steroids is not yet understood but the possible mechanisms have been summarised by Bishop and Glyn (1952). Whatever the mode of action of steroids proves to be, practically speaking the exhibition of these substances may (1) worsen pre-existing diabetes, (2) reveal laten diabetes, (3) produce diabetes in an individua who has evidence of pre-diabetes or (4) proo duce a diabetic syndrome without warning in: a patient who shows neither evidence of pres? diabetes nor latent diabetes.

The abnormalities of carbohydrate tolerance shown in the cortisone-augmented glucose tolerance tests in Cases 4 and 5 were more marked than those in the ordinary $50 \mathrm{~g}$. glucose tolerance tests in the same patients. Indeed in Case 3 the oral $50 \mathrm{~g}$. glucose tolerance test was normal while the response to $\overrightarrow{\vec{\psi}}$ cortisone-augmented glucose tolerance test was mildly diabetic. These results suggest that the cortisone-augmented glucose tolerance test iş. probably the more sensitive screening devices for use before steroid therapy is begun foi indicating those patients likely to develop $\$$ diabetic syndrome as a consequence of steroies administration.

\section{Summary}

A description is given of the clinical features and therapy of the diabetic syndrome whicls appeared in five patients who had receive $\bar{W}$ treatment with various steroids. In one oof $\overline{\mathrm{f}}$ these the diabetes appears to be permanen established after eight years, although no fan history or evidence of 'pre-diabetes' was đeo termined. In three of the remainder evidences of 'pre-diabetes' was noted.

The literature on steroid diabetes is reviewedo

We are greatly indebted to Dr. J. Basil Rennie and Dr. A. Girdwood Fergusson for permission to publish details of these patients. We would also like to thank Mr. Peter S. Waldie, Stobhill GeneraP Hospital, for Fig. 1 and Miss B. Newton, Assistan Librarian, Royal College of Physicians, Edinburgho for the numerous translations of articles from cono tinental journals.

\section{REFERENCES}

Baehr, G., Soffer, L. J., Boas, N. F., LevitT, M. F., and Gabrilove, J. L. (1950): The Influence of Cortisone and Adrenocorticotropin in Disseminated Lupus Erythematosus, Trans. Ass. Amer. Phycns., 63, 89.

BASTENIE, P. A. (1956): Steroid Diabetes in Man and its Relation to Ordinary Diabetes, in 'Cortico-surrénale et Diabète Humain'. Paris: Masson et Cie.

BERG, E. G. (1956): Ueber Schäden und Nebenwirkungen bei der therapeutischen Verwendung von Cortison un电. ähnliehen Steroid-hormonen, Münch. med. Wschr., 98, 1614.

BishOP, P. M. F., and GLYN, J. H., (1952): Diabetes caused by ACTH Treatment of Rheumatoid Arthritis Proc. roy. Soc. Med., 45, 168.

Bookman, J. J., Drachman, L. E., Schaefer, L. E., and AdLersberg, D. (1953): Steroid Diabetes in Man: Development of Diabetes during Treatment with Cortisone and Corticotropin, Diabetes, 2, 100.

BritTon, S. W. (1930): Adrenal Insufficiency and Relative Considerations, Physiol. Rev., 10, 617. Bunim, J. J., KaLTMAN, A. J., and MCEwEN, C. (1952): Diabetogenic Effect of Cortisone and ACTH in Nono
diabetic Patient with Rheumatoid Arthritis, Amer. J. Med., 12, 125. ConN, J. W., and FAJANS, S. S. (1956): Influence of Adrenal Cortical Steroids on Carbohydrate Metabolisnow
in Man, Metabolism, 5, 114.

Fajans, S. S., and ConN, J. W. (1954): An Approach to the Prediction of Diabetes Mellitus by Modification of the Glucose Tolerance Test with Cortisone, Diabetes, 3, 296. 
Golding, J. R. (1960): Triamcinolone, Postgrad. med. J., 36, 23.

Grilliat, J. P., Koenig, E., and Vaillant, G. (1959): Diabetes Occurring During the Deltacortisone therapy of Cirrhosis, Rev. méd. Nancy, 84, 720.

Gross, R., and Ludwig, H. (1956): High Dosage Prednisolone Therapy, Klin. Wschr., $34,1117$.

Herpers, G., (1957): Treatment of Ankylosing Spondylitis with Prednisone, Arzneimettel Forsch., $11,103$.

HuCZEK-GleBocKI, J., and OsterCZY, Z. (1959): Drug-induced Aplastic Anæmia complicated by Diabetes Mellitus during Cortisone Therapy, Pol. Tyg. lek., 14, 1662.

INGLE, D. J. (1941): The Production of Glycosuria in the Normal Rat by means of 17-hydroxy-11-dehydrocorticosterone, Endocrinology, 29, 649.

INGLE, D. J. (1956): Experimental Steroid Diabetes, Diabetes, 5, 187.

JACKSON, W. P. U. (1959): Prediabetes, Postgrad. med. J., 35, 287.

MACLean, K., and SchurR, P. (1959): Reversible Amyotrophy complicating Treatment with Fludrocortisone, Lancet, i, 701.

MacMahon, F. G. (1960): Steroid Diabetes, J. La. med. Soc., 112, 126.

Newman, S., Dobson, D., and Diraimondo, V. (1959): Evaluation of Metabolic Effects of Dexamethasone, Clin. Res., 7, 112.

PolaCHEK, A. A. (1955): Steroid Diabetes, Maryland med. J., 4, 195.

RANNey, H. M., and GellhoRn, A. (1957): The Effect of Massive Prednisone and Prednisolone Therapy on Acute Leukæmia and Malignant Lymphomas, Amer. J. Med., 22, 405.

Renold, A. E. (1959): Treatment of Diabetes Mellitus. Joslin, Root, White and Marble, 10th ed., p. 127. London: Henry Kimpton.

SELYE, H. (1946): The General Adaptation Syndrome and the Diseases of Adaptation, J. clin. Endocr., 6, 117.

SIMPSON, J. R. (1957): Steroid Diabetes-Case Report, Harper Hosp. Bull., 15, 43.

Sprague, R. G., Power, M. H., Mason, H. L., Albert, A., Mathieson, D. R., Hench, P. S., Kendall, E. C., Slocumb, C. H., and Polley, H. F. (1950a): Observations on the Physiological Effects of Cortisone and ACTH in Man, Arch. intern. Med., 85, 199.

Sprague, R. G., Hayles, A. B., Power, M. H., Mason, H. L., and Bennett, W. A. (1950b): Steroid Diabetes and Alkalosis associated with Cushing's Syndrome, J. clin. Endocr., 10, 289.

Tsukershtein, O. E. (1962): A Case of Diabetes Mellitus Developing under the Influence of ACTH and Cortisone, Probl. Endokr. Gormonoter, 8, 115.

Villa, L., Ballabio, C. B., and Sala, G. (1959): Clinical and Metabolic Effects of $16 \delta$-methyl-9 $\alpha$-fluorprednisolone or Dexamethasone, Ann. Rheum. Dis., 18, 170. 